\title{
Impact of some environmental factors on distribution of certain vector snails in five Egyptian Governorates
}

\author{
Abd El-Halim A. Saad ${ }^{1}$; Bayaumy B. Mostafa ${ }^{2}$; Samah Saad El-Din A. El-Magd ${ }^{3}$ and \\ Ahmed Mohamed A. Azzam ${ }^{2}$ \\ 1- Zoology Department, Faculty of Science, Ain Shams University \\ 2- Environmental Research Department. \\ 3- Clinical Microbiology Department, Theoder Bilharz Research Institute, P.O. Box 30 \\ Imbaba, Giza, Egypt.
}

\begin{abstract}
The present study showed that the distribution of the intermediate host snails of Fasciola sp. and Schistosoma sp. varied among the five surveyed Egyptian governorates. It was found that the ratios of distribution of Lymnaea natalensis, Bulinus truncatus and Biomphalaria alexandrina snails of the total surveyed sites were $44.1 \%, 26.9 \%$ and $4.9 \%$ respectively. Moreover, infected L. natalensis, B. truncatus and B. alexandrina snails in these sites were $1.96 \%, 3.4 \%$ and $0.98 \%$ respectively. However, infected $L$. natalensis and B. truncatus were found in Damietta and Beheira, while infected B. alexandrina were found only in Giza. Spring was the highest season in percentage of collected snails $(38.9 \%)$, while summer was the lowest one $(8.8 \%)$. L. natalensis, B. truncatus and B. alexandrina showed high distribution in Ismailia, Damietta and Giza governorates as represented by 4.16, 4.38 and $0.51 \mathrm{snails} / \mathrm{site}$ respectively. Some environmental factors were found affecting the distribution of snails. The means of $\mathrm{pH}$ and temperature in positive sites for vector snails were 6.8 and $26.7^{\circ} \mathrm{C}$ respectively. L. natalensis, B. truncatus appeared in water of electric conductivity mean of $415.5 \mu \mathrm{mhos} / \mathrm{cm}$ and $284.5 \mathrm{ppm}$ of mean total dissolved salts, while B. alexandrina was found at $481 \mu . \mathrm{mhos} / \mathrm{cm}$ and $603 \mathrm{ppm}$ respectively.
\end{abstract}

Keywords: Fasciola sp., Schistosoma sp., Lymnaea natalensis, Bulinus truncatus, Biomphalaria alexandrina, distribution

\section{INTRODUCTION}

Schistosomiasis and soil transmitted helminthes represent more than $40 \%$ of the global diseases burden caused by all tropical diseases, excluding malaria (WHO, 2006). Schistosomiasis is a chronic parasitic disease caused by blood flukes of the genus Schistosoma. More than 207 million people are so far infected worldwide, with more than $90 \%$ of the cases occurring in Africa, at poor communities without access to safe drinking water and adequate sanitation (WHO, 2011). In Egypt, ecological changes by the Aswan High Dam have resulted in more prevalence of S. mansoni in the Nile delta (El-Katsha and Watts, 1995). Wilmott (1987) reported that $S$. haematobium is still of predominance infection in Middle and Upper Egypt, while the ecological changes and irrigation practices have introduced S. mansoni and its snail vector B. alexandrina to these areas. Land reclamation extended the transmission of schistosomiasis to new areas in Egypt (El-Sayed et al., 1995). Khalil and Sleem (2011) stated that the latest report of the Egyptian Ministry of Health indicated that the percentage of infected people with Schistosoma has decreased significantly to only $4 \%$ compared to $45 \%$ during 1960 s. 
Fascioliasis is a parasitic disease of medical and veterinary importance that causes a great loss in livestock production (Mas-Coma and Bargues, 1997) and can also infect human (Mas-Coma et al., 1999). In Egypt, 830,000 people were found infected with liver flukes in the Nile Delta region (WHO, 1995). Soliman (1998) reported that until 1960, only sporadic human cases of fascioliasis were detected mainly in the Nile Delta. Since 1980, the number of cases has risen drastically and human infection has been reported in different governorates such as Giza, Qalyubia and Dakhlia (Haseeb, 2002). Fasciola is being enzootic in different livestock (Haridy et al., 2006). Mostafa et al. (2005) studied the distribution of vector snails of schistosomiasis and fascioliasis and infection risks at some rice farming in Kafr ElSheikh and Gharbia governorates. They found that $10 \%$ of sites in Gharbia and $19.95 \%$ in Kafr El-Sheikh were infested with infected B. alexandrina and B. truncatus snails respectively, while $L$. natalensis were found in $16.7 \%$ and $8.75 \%$ of the examined sites of the two governorates, respectively. Ashour et al. (2008) mentioned that the highest number of $L$. natalensis was collected from Giza (38 snails/site), while Kafr El-Sheikh had the lowest one ( 8 snails/site).

Also, some environmental factors affected the distribution of the intermediate host snails. El-Hawary (1990) found that high $\mathrm{pH}$ values up to 9.0 were detected in habitats free of snails. Snails were found by high number in water with salinity range of 340-600 ppm, but under concentration higher than $600 \mathrm{ppm}$, the number of snails decreased and they completely disappear at 1800 ppm (El-Said, 1997).

\section{MATERIAL AND METHODS}

Samples of snails in the present study were collected from 51 sites in four successive seasons from spring 2009 to winter 2010. These sites were distributed in five governorates, Giza (13 sites), Sharkia (3 sites), Ismailia (9 sites), Beheira (13 sites) and Damietta (13 sites). The selected sites were sampled using a standard dipnet (Yousif et al., 1992). The sampling started at the edge of canals water towards the stream midline, where the net was shaken in water after being filled with plants. The collected snails were placed in numbered plastic bags containing water and the bags were brought in cool boxes to the laboratory for counting, sorting and examined for natural trematode infection. Temperature and Hydrogen ion concentration $(\mathrm{pH})$ were measured by $\mathrm{pH}$ meter electrode (HANNA HI 9024). Electric conductivity and total dissolved salts were estimated by conductivity meter electrode (HANNA HI 9635). In the laboratory, collected snails were maintained in plastic aquaria containing dechlorinated tap water and a small amount of vegetation from the field. They were examined for larval trematodes by two methods: one by exposure of snails to natural or artificial light for one hour, at $25^{\circ} \mathrm{C}$, for cercarial shedding (Abdel Malek and Cheng, 1974), second by crushing of snails for detection of the interamolluscan stages, using a binocular microscope (Jackson, 1958).

So, the aim of this study is to evaluate the effect of some environmental factors on distribution of snail vectors of Schistosoma and Fasciola in certain water streams in Giza, Sharkia, Ismailia, Beheira and Damietta governorates.

\section{RESULTS AND DISCUSSION}

Table (1) shows that the total number of collected snails was 938 including 423 L. natalensis, 409 B. truncatus and 106 B. alexandrina (Fig. 1). Moreover, the spring was the highest season in ratio of collected snails $(38.9 \%)$ and represented $(51 \%)$ of 
infected snails, while summer was the lowest one $(8.8 \%$ and $3.7 \%)$ respectively (Fig. 2). El-Said (1997) reported that the cold seasons were more favorable for vector snails reproduction than warm ones.

Table 1: Total and infected snails collected during four seasons.

\begin{tabular}{|c|c|c|c|c|c|c|c|c|c|c|c|}
\hline \multirow[b]{3}{*}{ Seasons } & \multicolumn{9}{|c|}{ Snail population } & \multirow{3}{*}{$\begin{array}{l}\text { Total } \\
\text { collected } \\
\text { snails }\end{array}$} & \multirow[b]{3}{*}{$\% *$} \\
\hline & \multicolumn{3}{|c|}{ B. alexandrina } & \multicolumn{3}{|c|}{ B. truncatus } & \multicolumn{3}{|c|}{ L. natalensis } & & \\
\hline & $\begin{array}{c}\text { Total } \\
\text { No. }\end{array}$ & $\begin{array}{l}\text { Inf. } \\
\text { No. }\end{array}$ & $\begin{array}{l}\text { Non- } \\
\text { Inf. } \\
\text { No. }\end{array}$ & $\begin{array}{c}\text { Total } \\
\text { No. }\end{array}$ & $\begin{array}{l}\text { Inf. } \\
\text { No. }\end{array}$ & $\begin{array}{l}\text { Non- } \\
\text { Inf. } \\
\text { No. }\end{array}$ & $\begin{array}{c}\text { Total } \\
\text { No. }\end{array}$ & $\begin{array}{l}\text { Inf. } \\
\text { No. }\end{array}$ & $\begin{array}{l}\text { Non- } \\
\text { Inf. } \\
\text { No. }\end{array}$ & & \\
\hline Spring & 81 & 6 & 75 & 151 & 5 & 149 & 133 & 3 & 130 & 365 & 38.9 \\
\hline Summer & 1 & 0 & 1 & 26 & 0 & 26 & 56 & 1 & 55 & 83 & 8.8 \\
\hline Autumn & 20 & 1 & 19 & 118 & 7 & 111 & 75 & 0 & 75 & 213 & 22.7 \\
\hline Winter & 4 & 0 & 4 & 114 & 3 & 111 & 159 & 1 & 158 & 277 & 29.6 \\
\hline Total & 106 & 7 & 99 & 409 & 15 & 394 & 423 & 5 & 418 & 938 & 100 \\
\hline
\end{tabular}

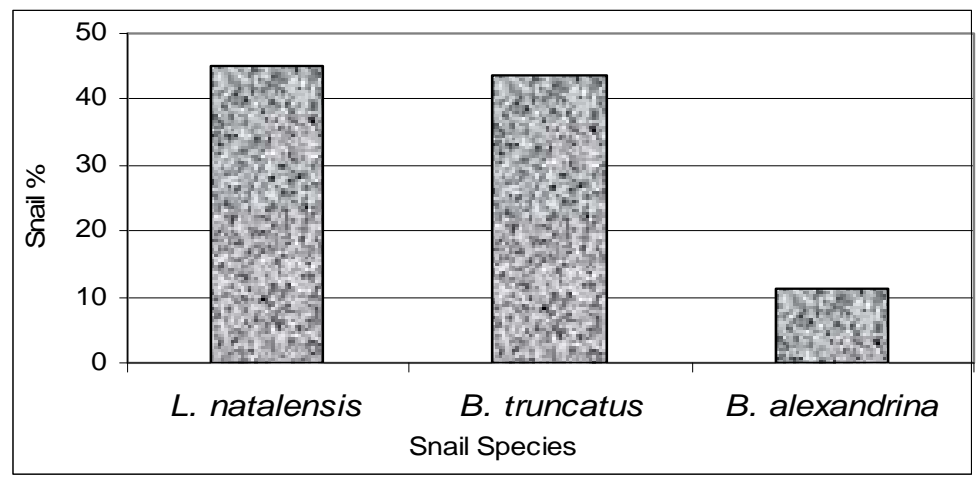

Fig. 1: Percentages of different snails species collected during four seasons.

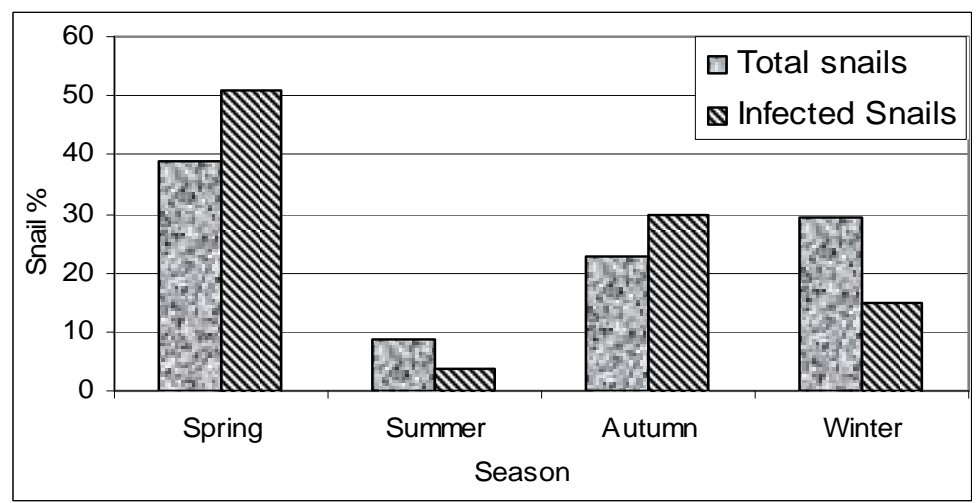

Fig. 2: Percentages of total and infected snails collected during four seasons.

The present data show that L. natalensis, B. truncatus and B. alexandrina snails were found in 90, 55 and 10 sites respectively, however, infected snails represented 4, 7 and 2 sites respectively of total surveyed sites during four seasons which agrees with Khalil and Sleem, (2011).

Table (2) shows the total number of different snails collected from the five governorates, L. natalensis counted 2.07 snails/site for all sites and represented the highest number (4.16 snails/site) in Ismailia, while Damietta, Giza, Skarkia and 
Beheira showed $2.44,1.38,1.33$ and 1.11 snails/site respectively. B. truncatus counted 2.0 snails/site for all sites and showed the highest in Damietta (4.38 snails/site), but Beheira, Ismailia, Skarkia and Giza reached 2.0, 1.38, 0.58 and 0.38 snails/site respectively. B. alexandrina were 0.51 snails/site for all sites, but were found by high number in Giza (1.94 snails/site), while Damietta 0.057 and Ismailia 0.055 snails/site and disappeared completely from Skarkia and Beheira governorates. Ashour et al. (2008) showed that the highest number of L. natalensis was collected from Giza (38 snails/site), while Kafr El-Sheikh had the lowest number (8 snails/site). Moreover, similar results were reported by Mostafa et al. (2005) and Haseeb (2002). Also, El-Azazy and Schillhorn (1983) stated that L. natalensis were most prevalent in the northern parts of the Nile Delta. Refaat et al. (2010) mentioned that the prevalence of Fasciola in Qena was 30.3\%, including $28.6 \%$ in cows, $33.7 \%$ in buffaloes and $17.2 \%$ in sheep.

Table 2: Number of different snails/site collected from five governorates during four seasons.

\begin{tabular}{|c|c|c|c|c|c|c|c|}
\hline \multirow{3}{*}{ Governorates } & \multirow{3}{*}{$\begin{array}{l}\text { No. of } \\
\text { sites } \\
\text { in } \\
\text { season }\end{array}$} & \multicolumn{6}{|c|}{ Snail Population } \\
\hline & & \multicolumn{2}{|c|}{ B. alexandrina } & \multicolumn{2}{|c|}{ B. truncatus } & \multicolumn{2}{|c|}{ L. natalensis } \\
\hline & & $\begin{array}{l}\text { No. of } \\
\text { Snails }\end{array}$ & $\begin{array}{c}* \text { Snail/ } \\
\text { Site }\end{array}$ & $\begin{array}{l}\text { No. of } \\
\text { Snails }\end{array}$ & $\begin{array}{c}* \text { Snail/ } \\
\text { Site }\end{array}$ & $\begin{array}{l}\text { No. of } \\
\text { Snails }\end{array}$ & $\begin{array}{c}\text { *Snail } \\
\text { Site }\end{array}$ \\
\hline Giza & 13 & 101 & 1.94 & 20 & 0.38 & 72 & 1.38 \\
\hline Sharkia & 3 & 0 & 0 & 7 & 0.58 & 16 & 1.33 \\
\hline Ismailia & 12 & 2 & 0.055 & 50 & 1.38 & 150 & 4.16 \\
\hline Beheira & 13 & 0 & 0 & 104 & 2.0 & 58 & 1.11 \\
\hline Damietta & 13 & 3 & 0.057 & 228 & 4.38 & 127 & 2.44 \\
\hline Total & 51 & 106 & 0.51 & 409 & 2.0 & 423 & 2.07 \\
\hline
\end{tabular}

Table (3) shows the percentage of infected snails that collected from different governorates. The total ratios of infection of B. alexandrina, B. truncatus and $L$. natalensis snails were $6.6 \%, 3.66 \%$ and $1.18 \%$ respectively. B. alexandrina infected snails were reported in Giza only, while B. truncatus and L. natalensis were found in Damietta and Beheira representing 4.82\% and 3.84\% respectively for $B$. truncatus and $1.72 \%$ and $3.14 \%$ respectively for $L$. natalensis. This finding was in accordance with Hariston (1973) who reported that low percentage of natural infection is the rule and it depends upon a complex interaction of different factors.

Table 3: Percentage of infected snails collected from five governorates.

\begin{tabular}{|l|c|c|c|c|c|c|c|c|c|}
\hline \multirow{2}{*}{ Governorate } & \multicolumn{3}{|c|}{ B. alexandrina } & \multicolumn{3}{c|}{ B. truncatus } & \multicolumn{3}{c|}{ L. natalensis } \\
\cline { 2 - 12 } & $\begin{array}{c}\text { No. } \\
\text { of } \\
\text { snails }\end{array}$ & $\begin{array}{c}\text { No. of } \\
\text { infected }\end{array}$ & $* \%$ & $\begin{array}{c}\text { No. } \\
\text { of } \\
\text { snails }\end{array}$ & $\begin{array}{c}\text { No. of } \\
\text { infected }\end{array}$ & $* \%$ & $\begin{array}{c}\text { No. } \\
\text { of } \\
\text { snails }\end{array}$ & $\begin{array}{c}\text { No. of } \\
\text { infected }\end{array}$ & $* \%$ \\
\hline Giza & 101 & 7 & 6.93 & 20 & 0 & 0 & 72 & 0 & 0 \\
\hline Sharkia & 0 & 0 & 0 & 7 & 0 & 0 & 16 & 0 & 0 \\
\hline Ismailia & 2 & 0 & 0 & 50 & 0 & 0 & 150 & 0 & 0 \\
\hline Beheira & 0 & 0 & 0 & 104 & 4 & 3.84 & 58 & 1 & 1.72 \\
\hline Damietta & 3 & 0 & 0 & 228 & 11 & 4.82 & 127 & 4 & 3.14 \\
\hline Total & 106 & 7 & 6.60 & 409 & 15 & 3.66 & 423 & 0 & 1.18 \\
\hline
\end{tabular}


However, low infection rate may reflect a small degree of biotic pollution but may also indicate a small proportion of susceptible snails in a population exposed to heavy pollution (Paraense and Correa, 1963) and agrees with (Khalil and Sleem, 2011).

Concerning to the effect of environmental factors on distribution of snail vectors, the means of water Hydrogen ion concentration $(\mathrm{pH})$ of positive sites for $L$. natalensis B. truncatus and B. alexandrina showed 6.8, 6.9 and 6.8 respectively, but snails completely diapered in $\mathrm{pH}$ more than 8 . Moreover, the means $\mathrm{pH}$ of positive sites for infected $L$. natalensis and B. truncatus snails were 7.4 and 7.0 respectively, while infected B. alexandrina was 6.6. This agrees with Carithers (2000) who mentioned that the Lymnaeid snails prefer slightly acidic pH. El-Emam and Roshdy (1981) showed that the number of the collected snails from El-Saff canal, Giza was very few in August 1980, where the $\mathrm{pH}$ value was relatively high (9.2). Similar results were obtained by (El-Hawary, 1990). Ashmawy et al., (1994) stated that pulmonata snails as Lymnaea sp., B. alexandrina and Bulinus sp. were collected from large as well as small canals in Beheira governorate and from narrow ditches, where $\mathrm{pH}$ ranged from 7.2 to 7.6 .

The snail vectors can tolerate a wide rang of temperature $18-34{ }^{\circ} \mathrm{C}$, but the highest ratio of snails $43.7 \%$ were found in temperature from 22.1 to $26^{\circ} \mathrm{C}$, while the highest ratio of infected snails $(81.4 \%)$ were collected from wider range of temperature (from 22.1 to $30^{\circ} \mathrm{C}$ ) (Fig.3). The mean temperatures of positive sites for L. natalensis and B. truncatus snails showed no substantial difference, represented by $26.9,26.4$ and $26.8^{\circ} \mathrm{C}$ respectively. The mean temperatures of positive sites for infected L. natalensis and B. truncatus snails showed slight difference $(27.8,25.0$, $27.0^{\circ} \mathrm{C}$ respectively). Azzam (2008) reported that the highest distribution of $L$. natalensis appeared during spring at a temperature range from 23 to $25^{\circ} \mathrm{C}$.

The present data also indicated that $72.3 \%$ of total snails and $51.8 \%$ of infected ones were collected under electric conductivity range of 301-600 $\mu . \mathrm{mhos} / \mathrm{cm}$, (Fig. 4). The means of electric conductivity of positive sites for L. natalensis B. truncatus and B. alexandrina were 416,415 and $481 \mu$. mhos/cm respectively, while for infected ones were 393, 604 and $707 \mu . \mathrm{mhos} / \mathrm{cm}$ respectively. This agrees with El-Emam and Roushdy (1981) who stated that the average water electric conductivity in the irrigation canals was $300 \pm 100 \mu . \mathrm{mhos} / \mathrm{cm}$.

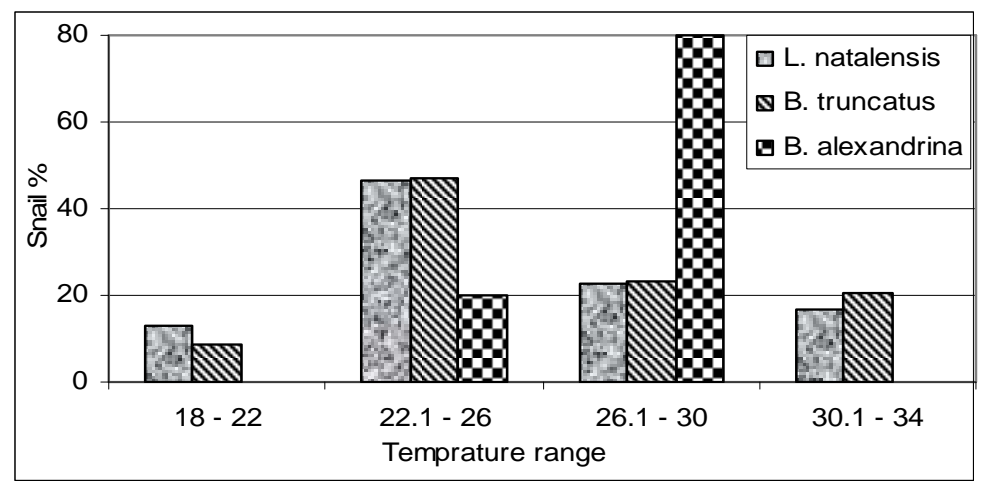

Fig. 3: Percentages of different snails species collected from water of different temperature. 


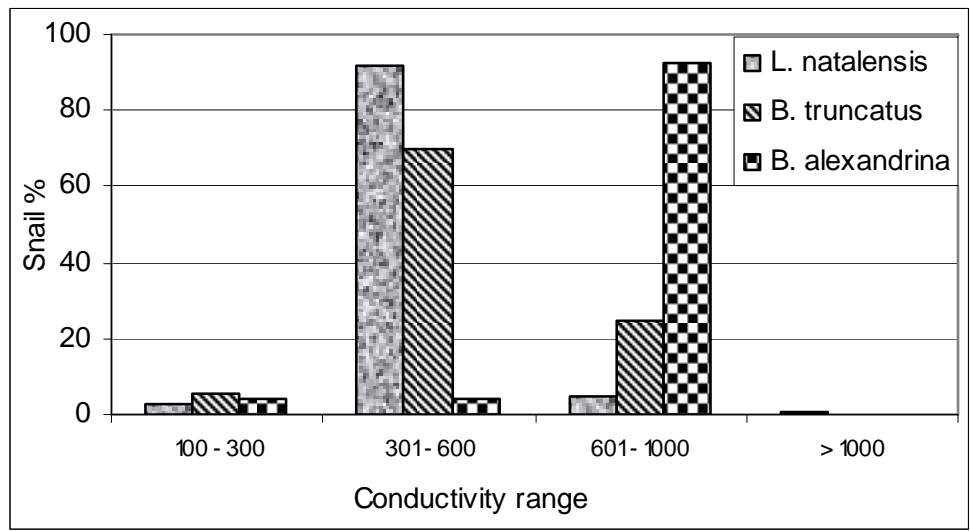

Fig. 4: Percentages of different snails species collected from water of different electric conductivity.

In the present study, the highest numbers of B. truncatus and $L$. natalensis snails were found under low total dissolved salts (TDS) of 100-300 ppm, but $B$. alexandrina snails were obtained from a range of 601-1000 ppm (Fig. 5). However, the means of TDS for positive sites of L. natalensis, B. truncatus and B. alexandrina snails represented 286, 283 and 603 ppm respectively, while infected snails were reported at 237, 391 and 870 ppm respectively. El-Said (1997) found higher snail numbers at total dissolved salts range of $340-600 \mathrm{ppm}$, while at higher levels than 600 ppm, the number of snail vectors of Fasciola sp. and Schistosoma sp. were decreased.

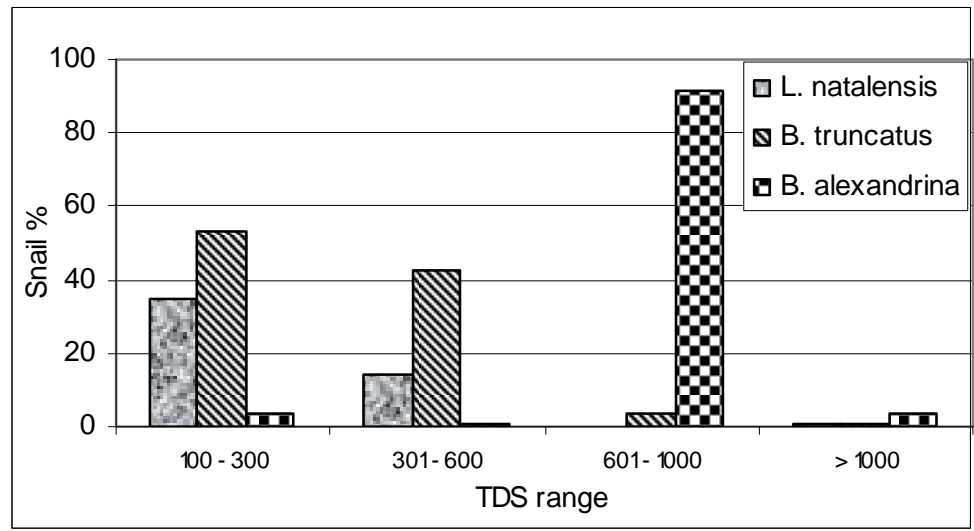

Fig. 5: Percentages of different snails species collected from water of different total dissolved salts (TDS).

\section{REFERENCES}

Abdel-Malek, E. and Cheng, T.C. (1974). Medical and economic malacology. Academic press, New York and London, pp. 54-101.

Ashmawy, K.; Abu-El-Wafa, S. A.; El-Bahi, M. M. and Diab, M. R. (1994). Incidence and ecology of freshwater snails in Beheira province. Assiut Vet. Med. J. 30(59):101-113.

Ashour, A.A.; Mostafa, B. B.; Taha, H. A. and Azzam, A. M. A. (2008). Distribution of natural populations of Lymnaea snails in some Egyptian Governorates and their natural infection with Fasciola. J. Environ. Sci., 16 (1): 19-31 
Azzam, A. M. A. (2008). Environmental factors related to prevalence of the snail intermediate hosts of Fasciola in some Egyptian governorates. M. Sc. Thesis Institute of Environmental studies and Researches, Ain-Shams Univ. Cairo, Egypt.

Carithers, D. (2000). The liver fluk (Fasciolia hepatica): Life cycle, epidemiology, pathology, clinical signs, effect on productivity, treatment and control. Merial Train. Bull. http://www.vet.ksu.edu/cdroms/merial/training/00003.htm

El-Azazy, O. M. E. and Schilhornan, T. W. V. (1983). Animal fascioliasis and schistosomiasis in Egypt and Sudan. Helminthol. Abst. Series A., 52:421-428.

El-Emam, M. and Roushdy, M. Z. (1981). Ecological studies on snail intermediate hosts of schistosomes in certain areas in Egypt. J. Egypt. Bilh., 8, (1-2).

El-Hawary, A. A. I. (1990). Some ecological and physiological studies on freshwater pollution and its relationship with the distribution of snail intermediate hosts of schistosomiasis in Egypt. M. Sc. Thesis, Faculty of Science, Cairo Univ., Egypt.

El-Katsha, S. and Watts, S. (1995). the public health implications of the increasing predominance of Schistosoma mansoni in Egypt: a pilot study in the Nile delta. J. Trop. Med. Hyg. 98:136-140.

El-Said, K.M. (1997). The effect of some freshwater pollutants on the snail vectors of schistosomiasis in Egypt. Ph.D. Thesis Institute of Environmental studies and Researches, Ain-Shams Univ. Cairo, Egypt.

El-Sayed, H.F.; Rizkalla, N. H.; Mehanna, S.; Abaza, S. M. and Winch, P. J. (1995): Prevalence and epidemiology of Schistosoma mansoni and S. haematobium infection in two areas of Egypt recently reclaimed from the desert. Am. J. Trop. Med. Hyg. 52: 194 -198 .

Haridy, F. M.; El-Sherbiny, G. T. and Morsy, T. A. (2006). Some parasitic flukes infecting farm animals in Al-Santa Center, Gharbia governorate, Egypt. J. Egypt. Soc. Parasitol., $36: 259-64$.

Hariston, N.G. (1973). The dynamics of transmission. In: "Epidemiology and Control of Schistosomiasis": Bilharziazsis. Published on behave of orld Health Organization by Schistosoma karger. Basel. Munchen. Paris. London. New York, Sydney ArmoldBochtin-Strasse 25, (H-4000 Basel 11, Switzerland).

Haseeb, A. N.; El Shazly, A. M.; Arafa, M. A. S. and Morsy, A. T. A. (2002). A review on fascioliasis in Egypt. Egypt. J. Soc. Parasitol., 32:317-354.

Jackson, J. H. (1958). Bilharzia, A background of its endemisity and control in Africa with particular reference to irrigation scheme. S. Afr. J. Lab. Clin. Med., 4(1):1-54.

Khalil, M. T. and Sleem, H. S. (2011). Can the freshwater crayfish eradicate schistosomiasis in Egypt and Africa? J. Am. Sci., 7(7):457-462.

Mas-Coma, S. and Bargues, M. D. (1997). Human liver flukes: a review. Res. Rev. Parasitol., 57: 145-218.

Mas-Coma, S.; Bargues, M. D. and Esteban, J. G. (1999). Human Fasciolosis. Dalton JP, ed. Fasciolosis. Wallingford, Oxon, United Kingdom: CAB International Publishing. 411434. 
Mostafa, B.; Abdel Kader, A. and Tantawy, A. (2005). Distribution of snail vectors of schistosomiasis and fascioliasis and infection risks at some rice farming sites in Kafer El-Sheikh and El-Gharbiya Governorates, Egypt: The present status. Egypt. Ger. J. Soc. Zool., 46(D):53-65.

Paraense, W. L. and Corrêa, L. R. (1963). Variation in susceptibility of population of Australorbis glabratus to a strain of Schistosoma mansoni. Rev. Institut. Med. Trop. Sao Paulo, 5: 15-22.

Refaat, M.; Khalifa, A.; Abdel-Nasser, A. and Hussein, A. (2010). Fascioliasis prevalences among animals and human in Upper Egypt. J. King. Saud. Univ. Sci., 22(1):15-19.

Soliman, M.S. (1998). Control of veterinary fascioliasis. Angelico M, Rocchi G, eds. Infectious Diseases and Public Health. A Research and Clinical Update. Philadelphia: Balaban Publishers, 334-346.

WHO (1995). Control of foodborne trematode infections. World Health Organ. Tech. Rep. Ser. 849:1-157.

WHO (2006). Schistosomiasis and soiltransmitted Helminth infection spreliminary estimates of the number of children treated with albendazole or mebendazole. Weekly Epidemiol. Rec., 81: 45-64.

WHO (2011). Schistosomiasis: number of people treated worldwide in 2009. Weekly Epidemiol. Rec., 9:73-80

Wilmott, S. E. (1987). Report of an independent evaluation mission on the National Bilharzia Control Programme in Egypt, 1985, Trans.R. Soc. Trop. Med. Hyg. (Suppl.) 81:1-87.

Yousif, F.; Khalil, M. and El-Emam, M. (1992). Evaluation of three common tools in estimating Biomphalria alexandrina population in irrigation ditches. Egypt. J. Bilh. 14:151-158.

\section{ARABIC SUMMARY}

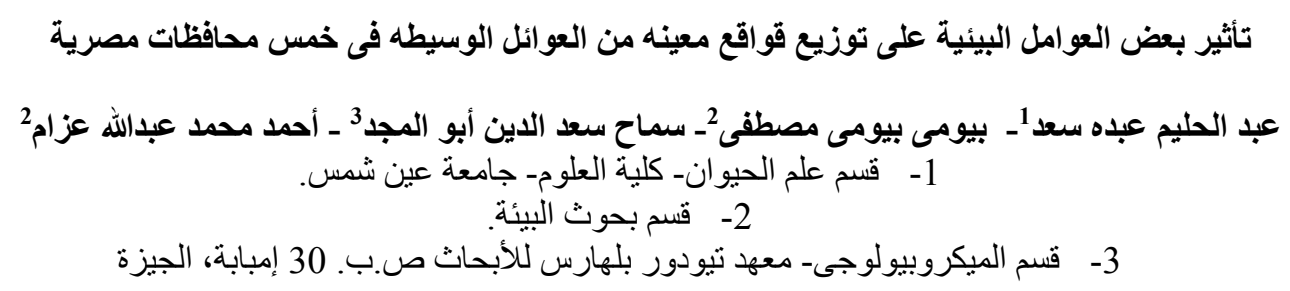

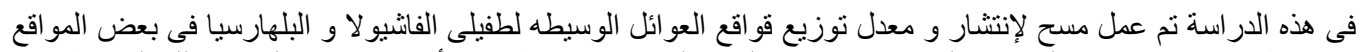

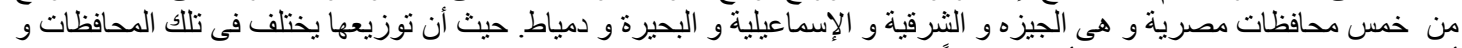

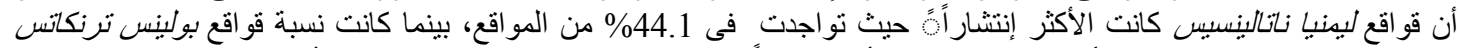

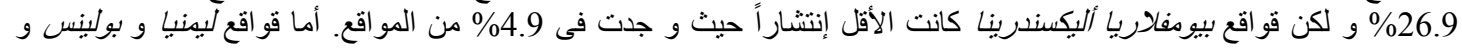

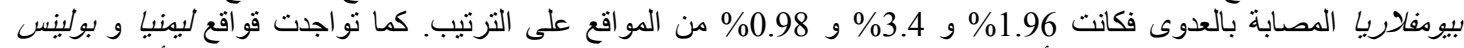

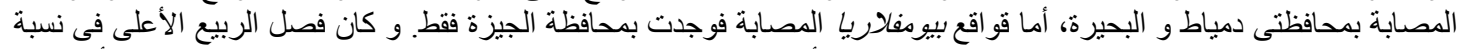

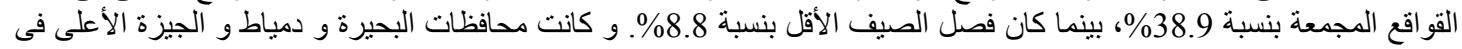

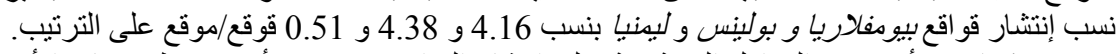

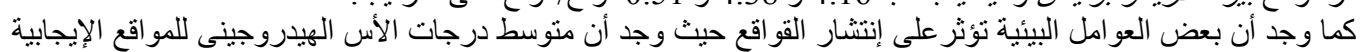

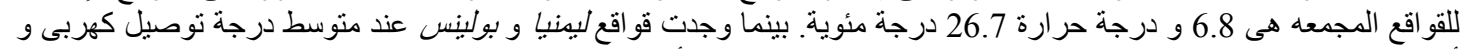

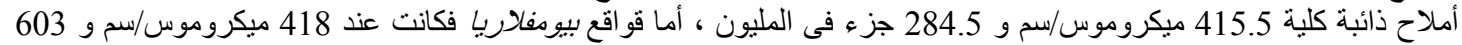

